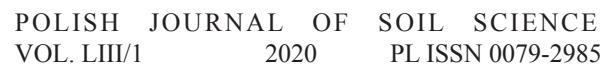

DOI: $10.17951 / \mathrm{pjss} / 2020.53 .1 .117$

\title{
JOZEF KOBZA*, BORIS PÁLKA** \\ BASIC PROPERTIES OF AGRICULTURAL BLACK SOILS IN SLOVAKIA USING THE INBS CRITERIA
}

Abstract. Distribution of black soils in Slovakia using the International Network of Black Soils (INBS) is evaluated in this paper. Numerous soil profiles (17,620 soil profiles from the complex soil survey of agricultural land and 318 monitoring sites in Slovakia) have been reviewed for their evaluation. According to the INBS criteria, the following parameters were evaluated: thick layer of humus, soil organic carbon (SOC) and soil organic matter (SOM) as well as a base saturation. In addition, some qualitative parameters of dark-coloured soils have been also evaluated (i.e. total nitrogen content $-\mathrm{N}_{\text {tot }}, \mathrm{C} / \mathrm{N}$ ratio, $\mathrm{C}_{\mathrm{HA}} / \mathrm{C}_{\mathrm{FA}}$ ratio and colour quotient $\mathrm{Q}_{6}^{4}$ ). On the basis of obtained results there was determined that the area of black soils, according to the INBS criteria, represents $93,654.63$ ha which constitutes $19.7 \%$ of all black soils mapped according to land and ecological evaluation units and $3.92 \%$ of total agricultural soils in Slovakia. According to the INBS criteria, black soils are characterised by average thick humus layer of $57 \mathrm{~cm}$ and SOC content of $2.66 \%$ as well as $4.58 \%$ of SOM with high base saturation (96.65\%).

Keywords: black soils, INBS criteria, soil survey, soil monitoring

* Department of Geography and Geology, Faculty of Natural Science, Matej Bel University, Banská Bystrica. Corresponding author's e-mail: jozef.kobza@nppc.sk

** National Agricultural and Food Centre - Soil Science and Conservation Research Institute Bratislava. 


\section{INTRODUCTION}

The launch of the International Network of Black Soils took place during the Global Symposium on Soil Organic Carbon (21-23 March 2017) organized by the Global Soil Partnership (GSP) at FAO headquarters in Rome, Italy. "Black soils" is a term used in some national soil classification systems that may cover different types of soil. The term "black soils" covers the soils with dark grey to black colour, included in various soil classification systems, e.g. in India these soils are classified as Vertisols (Roy and Barde 1962). In China, these soils correspond with high content of soil organic matter (6-8\%) (Wen and Liang 2001). It may be said that black soils are great group of the Chernozemic Order and are associated with sub-humid climates and tall-grass native vegetation and have a relatively thick, black A humic horizon. Black soils correspond with Mollisols in the USDA soil taxonomy, while in the WRB system (FAO 2014), black soils would correspondent with three different but related reference soil groups: Chernozems, Kastanozems and Phaeozems. According to the preliminary analysis, 62 countries in the world have more than $5 \%$ of black soils - in the EU these are Bulgaria, the Czech Republic, Hungary, Romania and Slovakia (Kobza and Pálka 2017). Using the national soil classification system of Slovakia, these soils are classified as Chernozems (černozeme) and Phaeozems (čiernice) (Societas pedologica slovaca 2014).

\section{MATERIALS AND METHODS}

Given the different perceptions of black soil, this group of soils is defined under the INBS as soils containing:

- a thick layer of humus (minimum thickness of $25 \mathrm{~cm}$ ),

- SOC content greater than $2 \%$ and minimum SOM content of $2 \%$ up to $20 \%$ (histic epipedons are excluded),

- high base saturation (greater than 50\%: umbric, also melanic and fulvic epipedons are excluded),

- are well drained (poorly-drained soils and Aquolls are excluded).

In addition, we evaluate also some qualitative parameters of soil organic matter $\left(\mathrm{C} / \mathrm{N}, \mathrm{C}_{\mathrm{HA}} / \mathrm{C}_{\mathrm{FA}}, \mathrm{N}_{\text {tot }}, \mathrm{Q}_{6}^{4}\right)$ in soil profiles of black soils situated in Slovakia where the following analytical procedures have been used:

- determination of total carbon using $\mathrm{CN}$ analyzer,

- determination of total nitrogen according to Jodlbauer,

- determination of $\mathrm{C}_{\mathrm{HA}}$ and $\mathrm{C}_{\mathrm{FA}}$ and optical properties according to Kononova and Bel'čikova.

All methods are described in more details in the book of analytical procedures (Kobza et al. 2011). It was used the database of soil information system 
in Slovakia where 341 soil profiles of soil survey and 36 soil profiles of soil monitoring system concerning black soils (according to the INBS criteria) were evaluated. Graphical outputs and mathematic/statistical evaluation of soil profiles data were evaluated in GIS.

\section{RESULTS AND DISCUSSION}

The common feature of black soils is accumulation of organic matter of chernozemic type with creation of mollic diagnostic horizon. Therefore, these soils are made up of very dark topsoil rich in organic matter and highly saturated with bases cations with neutral reaction ( $\mathrm{pH}$ in $\mathrm{CaCl}_{2} 6-7.5$ ). Black soils in Slovakia create relatively homogenous associations of soils with low degree of internal contrast of soil structure.

Black soils are mostly situated in southwestern part of Slovakia and belong to the most fertile soils practically used as arable land (Fig. 1). These soils are also visible in other parts of Slovakia. In addition, the phenomenon of (paleo) hydromorphism (Phaeozems) appears. These soils are situated often in cool and moist regions with inclination of $3-5^{\circ}$ and more, often with the skeleton content in the soil profile (Kobza 2004). On the basis of interpolation of evaluated soil profiles of black soils (using soil database of the Slovak Republic) these soils are situated on the area of $93,654.63$ ha (3.92\% of agricultural land of Slovakia). Selected soil profiles of black soils using the INBS criteria are shown in Figs. 1 and 2 (Chernozem). In addition, according to some micromorphological studies, in this case the brown diffusely dispersed forms of humus were indicated (Čurlík 1975). It was also confirmed by detailed quaternary geological researches in which they were described as deluvial or proluvial sediments, especially works

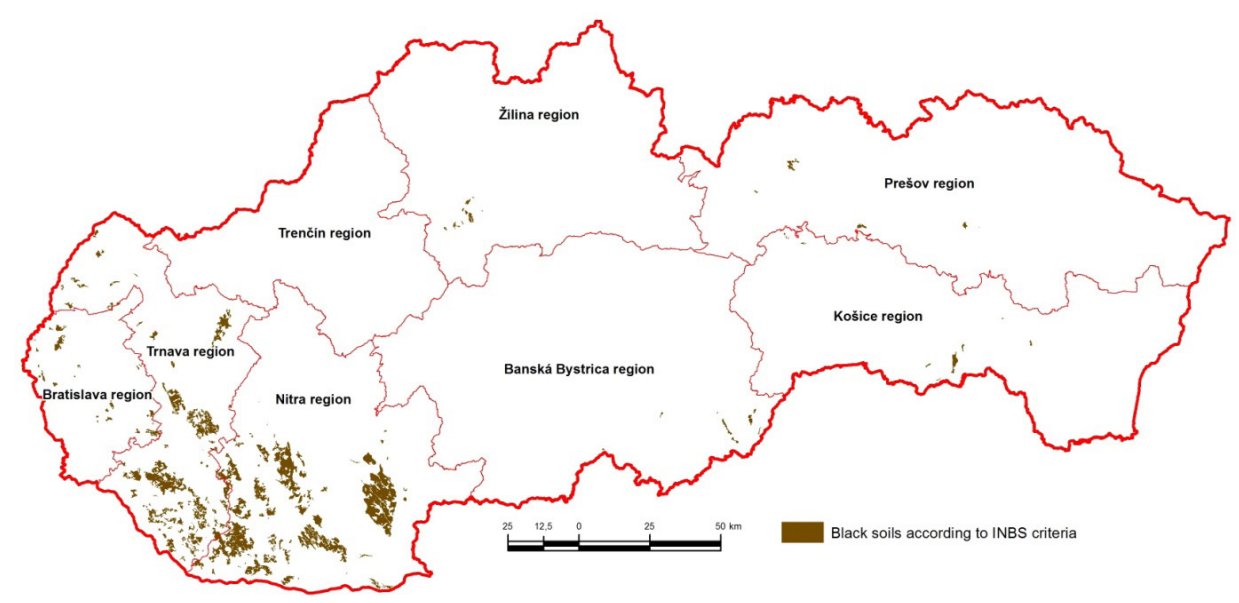

Fig. 1. Distribution of black soils in Slovakia according to the INBS criteria 
from the eastern part of the Danubian Lowland (Podunajská nižina) (Vaškovský and Halouzka 1976, Koštialik 1974). In addition, there are also "black soils" (outside of the INBS criteria) with a shallower A horizon $(<25 \mathrm{~cm})$ which are also situated in the soil cover of Slovakia probably under the influence of erosion (eroded forms) - Fig. 3 (Chernozem). A question arises whether the INBS criteria for black soils evaluation are reliably sufficient or not? Basic statistical characteristics of black soils in Slovakia according to the INBS criteria are given in Table 1.

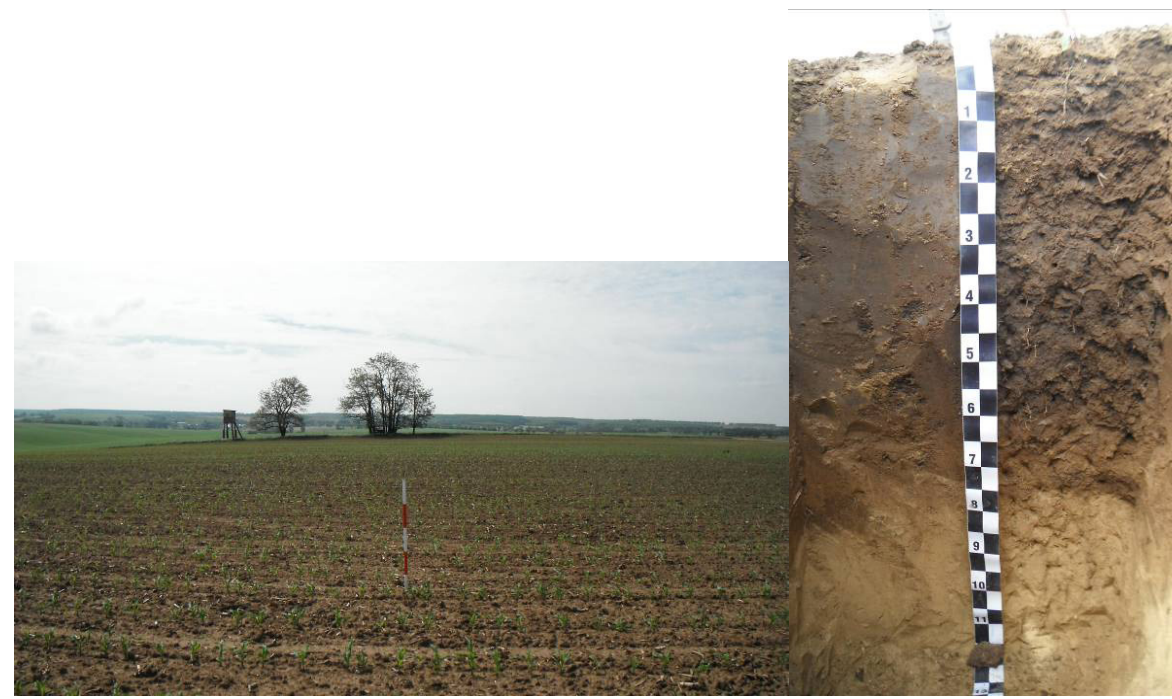

Fig. 2. Example of black soil (Chernozem) according to the INBS criteria (Rišňovce)

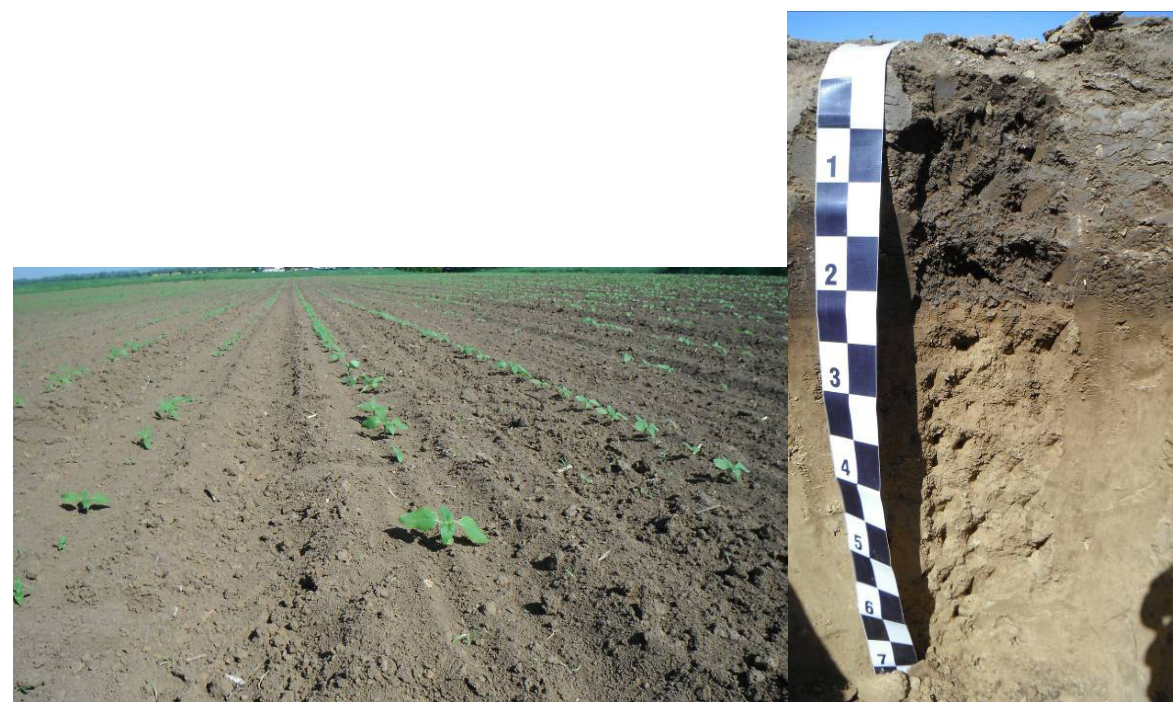

Fig. 3. Example of "black soil"(Chernozem) where the INBS criteria are not met (A hor. $<25 \mathrm{~cm})$ (Jaslovee) 
Table 1. Basic statistical parameters of black soils in Slovakia according to the INBS criteria (A horizon $\geq 25 \mathrm{~cm}$ )

\begin{tabular}{cccccc}
\hline Parameters & $\mathrm{X}_{\min }$ & $\mathrm{X}_{\max }$ & $\mathrm{X}$ & $\mathrm{Sd}$ & $\mathrm{Vc}(\%)$ \\
\hline Depth of A hor. (cm) & 27 & 140 & 57 & 14.90 & 26 \\
\hline SOC (\%) & 2.01 & 9.68 & 2.66 & 0.86 & 32 \\
\hline BS (\%) & 54.34 & 100 & 96.65 & 7.60 & 8 \\
\hline $\mathrm{N}_{\text {tot }}\left(\mathrm{mg} \cdot \mathrm{kg}^{-1}\right)$ & 1541 & 4140 & 2281 & 495.9 & 22 \\
\hline $\mathrm{C} / \mathrm{N}$ & 8.08 & 11.57 & 9.79 & 0.89 & 9 \\
\hline $\mathrm{C}_{\mathrm{HA}} / \mathrm{C}_{\mathrm{FA}}$ & 0.60 & 2.75 & 1.28 & 0.56 & 44 \\
\hline $\mathrm{Q}_{6}^{4}$ & 3.59 & 5.50 & 4.41 & 0.52 & 12 \\
\hline
\end{tabular}

Note: $\mathrm{X}_{\min }$ - minimum value, $\mathrm{X}_{\max }$ - maximum value, $\mathrm{X}$ - arithmetic mean, $\mathrm{Sd}$ - standard deviation, $\mathrm{Vc}$ - variable coefficient, $\mathrm{SOC}$ - soil organic carbon, BS - base saturation, $\mathrm{N}_{\text {tot }}$ - total nitrogen, HA - humic acids, $\mathrm{FA}$ - fulvoacids, $\mathrm{Q}_{6}{ }_{6}-$ colour quotient

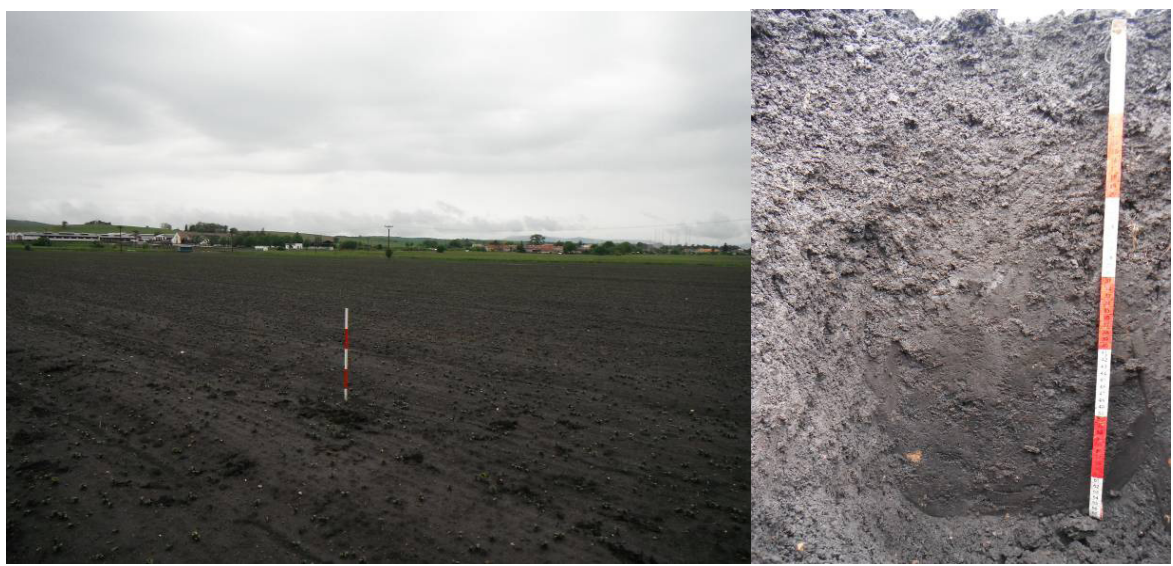

Fig. 4. Example of black soil (Phaeozem) with buried A horizon (Žíp)

The depth of A horizon of black soils using the INBS criteria (where A horizon $\geq 25 \mathrm{~cm})$ is running in wide range $(27-140 \mathrm{~cm})$, average value is $57 \mathrm{~cm}$. Soil organic carbon content is also variable (2.01-9.68\%), average value is $2.66 \%$. Finally, base saturation is more than $50 \%$, average value is $96.65 \%$. The predominant pedological process is the accumulation of soil organic matter which is more significant under (paleo) hydromorphic conditions. In the framework of complicated pedogenesis, during the change of hydromorphic to automorphic conditions, it is sometimes possible to observe the occurrence of old buried humus horizon covered by younger deposits (Fig. 4). In this case the age of buried A horizon was about 7,000 years old - using the radioactive isotope of ${ }^{14} \mathrm{C}$. As we mentioned before, the evaluation of qualitative parameters would also be useful for characteristics of black soils (Kobza and Pálka 2017). According to the obtained results of soil monitoring system in Slovakia, the important basic parameters of soil organic matter of black soils are given in Table 1. The average content of total nitrogen in black soils of Slovakia was calculated 2281 
mg.kg-1 which is the medium content (Bielek 1998). Average values of $\mathrm{C} / \mathrm{N}$ are one of the main indicators of humus quality (Sotáková 1982) and a good indicator of the dynamics of soil quality (Franzluebbers 2002). The values of $\mathrm{C} / \mathrm{N}$ ratio are even-tempered and are in the range of 8.08-11.57 (average value 9.79).

In addition, the basic qualitative indicator of soil humus is the humic acid to fulvoacids ratio $\left(\mathrm{C}_{\mathrm{HA}} / \mathrm{C}_{\mathrm{FA}}\right)$. The values higher than 1 indicate well ripened and humificated soil organic matter. It is also confirmed by colour quotient $\mathrm{Q}_{6}^{4}$ with an average value of 4.41 which is the lowest value of colour quotient in soils of Slovakia and refers to soil organic matter with high quality (Š́ály 1978, Sotáková 1982, Kobza et al. 2019).

\section{CONCLUSIONS}

Black soils, according to the INBS criteria, are situated on the area of 93,654.63 ha which is 3.92\% of total agricultural land in Slovakia. It may be said that there are also "black soils" in Slovakia where some of the INBS criteria are not met (e.g. the depth of molic humus horizon less than $25 \mathrm{~cm}$ ). According to the INBS criteria, black soils in Slovakia are characterised by a deep mollic humus horizon (average depth $57 \mathrm{~cm}$ ), average content of soil organic carbon $(2.66 \%)$ and average base saturation (96.65\%). In addition, qualitative parameters of black soils are also significant. Total content of nitrogen is medium (average value $2281 \mathrm{mg} \cdot \mathrm{kg}^{-1}$ ) which is also confirmed by the $\mathrm{C} / \mathrm{N}$ ratio (average value 9.79). Black soils are characterised by well humificated soil organic matter with $\mathrm{C}_{\mathrm{HA}} / \mathrm{C}_{\mathrm{FA}}$ ratio $>1$ and with a low value of colour quotient $\left(\mathrm{Q}^{4}{ }_{6}=4.41\right)$ which is the lowest value of all agricultural soils in Slovakia.

\section{ACKNOWLEDGEMENTS}

This research was financially supported by the project No. 471/2014-310/ MPRV SR (Ministry of Agriculture and Rural Development of the Slovak Republic).

\section{REFERENCES}

[1] Bielek, P., 1998. Nitrogen in agricultural soils of Slovakia. Bratislava: VÚPÚ, 256 p. (in Slovak).

[2] Čurlík, J., 1975. Mineralogical composition of agricultural soils in Slovakia. Final report (in Slovak).

[3] FAO, 2014. World reference base for soil resources. International soil classification system for naming soils and creating legends for soil maps. FAO Rome, 2014, $192 \mathrm{p}$. 
[4] Franzluebbers, A.J., 2002. Soil organic matter stratification ratio as an indicator of soil quality. Soil Tillage Research, 66: 95-106.

[5] Kobza, J., 2004. Contribution on genesis of dark-coloured soils in non-chernozems regions of Slovakia and problem of their classification. Proceedings of Soil, Science and Conservation Research Institute, Bratislava, 26: 151-158.

[6] Kobza, J., Hrivňáková, G., Makovníková, J., Barančíková, G., Bezák, P., Bezáková, Z., Dodok, R., Grečo, V., Chlpík, J., Lištjak, M., Mališ, J., Píš, V., Schlosserová, J., Slávik, O., Styk, J., Širáň, M., 2011. Unified analytical procedures for soil. Soil Science and Conservation Research Institute Bratislava, 135 p. (in Slovak).

[7] Kobza, J., Pálka, B., 2017. Contribution to black soils in Slovakia according to the INBS criteria. Proceedings of National Agricultural and Food Centre. Soil Science and Conservation Research Institute, Bratislava, 34-42 (in Slovak).

[8] Kobza, J., Barančíková, G., Dodok, R., Makovníková, J., Pálka, B., Styk, J., Širáň, M., 2019. Soil monitoring of the Slovak Republic. Current state and development of monitoring soil properties as a basis to their protection and next land use. National Agricultural and Food Centre. Soil Science and Conservation Research Institute Bratislava, 252 p (in Slovak).

[9] Koštialik, J., 1974. Characteristics and stratigraphy of fossile soils and loesses of Nitrianska pahorkatina (downland). Náuka o Zemi, VIII. Pedologica 9. Bratislava: Veda, 134 p. (in Slovak).

[10] Roy, B., Barde, N.K., 1962. Some characteristics of the Black Soils of India. Soil Science, 93(2):142-147.

[11] Societas pedologica slovaca, 2014. Morphogenetic Soil Classification System of Slovakia. Bratislava, 96 p. (in Slovak).

[12] Sotáková, S., 1982. Soil organic matter and soil fertility. Bratislava: Príroda, 236 p. (in Slovak).

[13] Šály, R., 1978. Soil - a base of forest production. Zvolen: VŠLD, 229 p. (in Slovak).

[14] Vaškovský, I., Halouzka, R., 1976. Geological map of Podunajská nižina (lowland). Southeast part, 1:500 000. Bratislava: GÚDŠ (in Slovak).

[15] Wen, D., Liang, W., 2001. Soil fertility quality and agricultural sustainable development in the black soil region ofnortheast China. Environment, Development and Sustainability, 3(1): 31-43. DOI: 10.1023/A:1011480228613. 